\title{
The Influence of Some Synthesis Compounds on Healthy and Tumoral Oral Cell Lines: PGK, HGF and SCC4
}

\author{
RAZVAN SUSAN ${ }^{1 *}$, ION VIRGIL CORLAN" ${ }^{2 \#}$, DELIA BERCEANU VADUVA ${ }^{1 *}$, RAMONA POPOVICl2*, MATILDA RADULESCU ${ }^{1}$, \\ MONICA SUSAN ${ }^{1}$, ALIN FAUR ${ }^{1}$, ADELINA CHEVERESAN ${ }^{1}$ \\ ${ }^{1}$ Victor Babes University of Medicine and Pharmacy, Faculty of Medicine, 2 EftimieMurgu Sq., 300041, Timisoara, Romania \\ ${ }^{2}$ Victor Babes University of Medicine and Pharmacy, Faculty of Dentistry, 2 EftimieMurgu Sq., 300041, Timisoara, Romania
}

\begin{abstract}
This presentstudy aimed to assess the influence of different chemical compounds which are commonly found in the composition of products used for oral hygiene on primary gingival keratinocyte, human gingival fibroblast and tongue squamous cell carcinoma behaviour. Chlorhexidine (Chx), aspartame (Asp), xylitol (Xyl) and sodium bicarbonate ( $\mathrm{NaB}$ ) were evaluated in an in vitroresearch regarding cells morphology and cytotoxicity. Primary gingival keratinocytes (PGK)and fibroblasts (HGF) treated with different concentration of the tested compounds did not show significantchanges, nor related to morphology nor related to viability at the low est concentrations used $(<25 \mu \mathrm{M})$. In contrast, the tumor cells were affected by the test compounds, especially xylitol and sodium bicarbonate, both in terms of morphology and cytotoxicity, at concentrations over $5 \mu \mathrm{M}$.
\end{abstract}

Keywords: chlorhexidine, aspartame, xylitol, sodium bicarbonate, oral cells

Oral care products (for teeth and mouth care) are available as toothpaste, mouthwash, tooth whitening products, denture care products etc. Before placing on the market, they pass through standard safety assessments and are approved by regulatory bodies. However, in various situations, side effects have been reported. Specialty studies that treat biocompatibility and adverse reactions due to these types of products are in minority compared to those that treat their efficacy. The main reasons are: (i) the passive oral exposure of tissues to these products due to the short contactperiod between them and the preferential sponsorship of research which aim to evaluate the positive regards of oral care products in terms of efficacy and clinical performance compared to research which aim to assess adverse effects of these products [1].

Chlorhexidine is a bisbiguanide base, used as antiseptic with an important antimicrobial activity which is utilizedin different forms (digluconate, hydrochloride, and acetate) being present inmouth rinse - $0.2 \%$, gel - $1 \%$, spray - $0.2 \%$, toothpaste - $1 \%$, root canal irrigant- $2 \%$, varnishes, and periodontal chips (as antimicrobial agent) [1]. Even if it is the gold standard in his area exerts some oral side effects like: brown staining of teeth, mucosa, and restorations [2], taste disturbance [3], oral mucosal erosion, parotid swelling, and enhanced supragingival calculus formation [4].

Aspartame (E951), was discovered in 1965 and is synthetized through the combination of amino acids, namely L-phenylalanine, L-aspartic acid, and connected through methyl ester bonds being considered a source of phenylalanine (which must be considered for people with phenylketonuria) [5]. In literature, are data which describe the toxicity and hepatocellular alteration in long-term exposure to it [6].Currently is investigated for its safety, even if wasgenerally recognized as safe. Some pathologies are linked with his nephrotoxicity, hepatotoxicity, and damage to nerves, cancer, and even type 2 diabetes [ 7 10].

Xylitol (E967), a five-Cpolyol, synthesized by hydrogenation of xylose (for the first time in 1891) presents around $95 \%$ sweetness of sucrose being the sweetest compound from its class, contributing with $2.4 \mathrm{kcal} / \mathrm{g}$. Can be also obtained by different extraction methods from birch and other woods, almond husks, corncobs, straw and paper production surplus. Can be found in many fruits and vegetables $[1,10]$.

Sodium bicarbonate exerts an antibacterial effect because presents cleansing action by loosening debris and dissolving mucus. Due to the increase values of the $\mathrm{pH}$ in the oral cavity after administration of the compound, can be prevented theovergrow th of acidophilic bacteria. Some studies pointed out that mouthwash withNaHCO $1 \%$ causes less irritation to the oral mucosa in a group of sensitive cancer patients as compared with other similar products [1].

The present study was proposed to assess the activity on normal and tumoral oral cell lines of four different chemical compounds found in oral care products: chlorhexidine (Chx), aspartame (Asp), xylitol (Xyl) and sodium bicarbonate ( $\mathrm{NaB})$.

\section{Experimental part}

Materials and methods

Chemicals and reagents

All chemical reagents and standard substances used were of analytical reagent grade and obtained from SigmaAldrich and Merck (Germany). The chemical compounds stock solutions used were initially dissolved in complete medium, Dulbecco's Modified Eagles Medium(DMEM) at concentrations of $10 \mathrm{mM}$ for chlorhexidine and sodium bicarbonate, and $1 \mathrm{mM}$ for aspartame and xylitol, respectively. After preparation, the stock solutions were filtered through a $0.22 \mathrm{~mm}$ filter and diluted with medium in order to obtain the finalworking concentrations (adjusted to $\mathrm{pH}$ 7.4) used within the tests.

\section{Cells culture}

The cell lines utilized in the current experiments were primary gingival keratinocytes and fibroblasts (normal/ 
healthy cells - PGK and HGF) and tongue carcinoma (tumor squamous cells - SCC4) purchased from American Type cell Collection, commercial forms - frozen vials. The specific medium for cells culture and kit, like: Dermal Cell Basal Medium (DMEM), Fibroblast Basal Medium (FBM) and Dulbecco's Modified Eagle's Medium/Ham's Nutrient Mixture F-12 (DME:F12), Keratinocyte Growth Kitand MTT were supplied from Sigma Aldrich and ATCC. Other characteristic reagents among whichfetal bovine serum (FBS), phosphate saline buffer (PSB), trypsin, ethylenediaminetetraacetic acid (EDTA), penicillin and streptomycin mixture, Trypan Blue,hydrocortisone were purchased from Sigma Aldrich, Merck and ATCC.

The cells exposed to various concentrations of Chx, Asp, $\mathrm{Xyl}, \mathrm{NaB}(1,5,10,25$ and $50 \mu \mathrm{M})$ over three time periods (24 hours) were examined under a phase-contrast microscope for any changes in their attachment to the culture flask, size, shape, integrity of their cell characteristics.

The MTT cell viability assay was used and the protocol was adapted from the literature [11]. In brief, the cells were seeded in 96-well cell culture plates and exposed to the test compounds as mentioned above. After incubation period ( 24 hours), the MTT solution was added to each well and the culture plates were incubated at $37^{\circ} \mathrm{C}$ for 4hours and after removal of the liquids from the wells DMSO was added in order to dissolve the formazin crystals and the absorbance was read at $540 \mathrm{~nm}$ with a reference wavelength of $690 \mathrm{~nm}$. Results were expressed as \% cell viability.

$10 \mu \mathrm{M}$
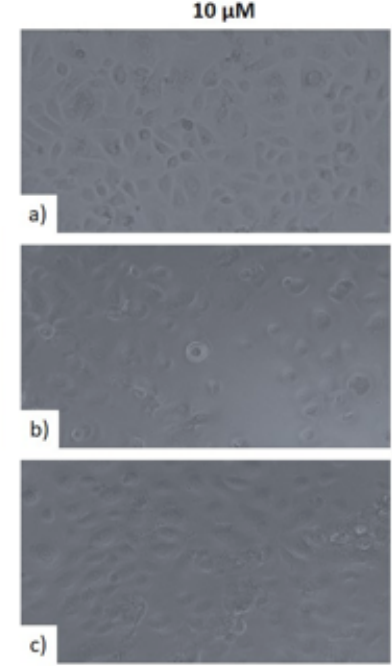

$10 \mu \mathrm{M}$

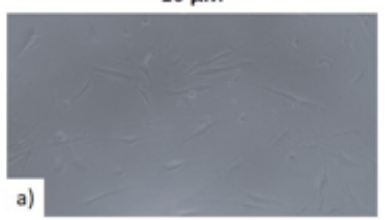

Control
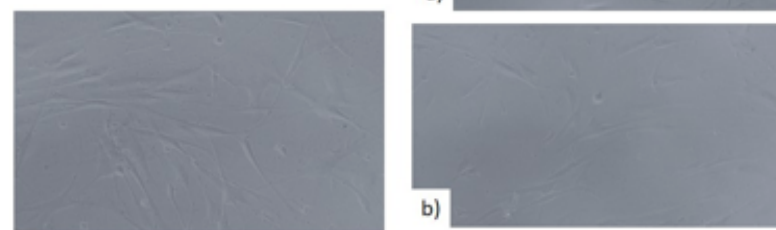

\section{Statistical analysis}

The statistical and software programs applied in the present study were GraphPad Prism 7. Data wereprocessed using One-way Anova followed by Tukey's post-tests, in order to establish the statistical difference groups; *, **, $* * *$ and $* * * *$ indicate $\mathrm{p}<0.05, \mathrm{p}<0.01, \mathrm{p}<0.001$ and $p<0.0001$, respectively.

\section{Results and discussions}

\section{Cells morphology.}

The cells were observed to have an intact morphology and a similar size and shape as the untreated controls up to a concentration of chemical compounds of approximately $25 \mu \mathrm{M}$. Cells presented clear morphological changes when observed under the phase-contrast microscope after exposure to test compounds in excess of $50 \mu \mathrm{M}$, after $24 \mathrm{~h}$ post-stimulation. They lose their welldefined form as can be observed in the figures 1-3.

\section{Cells viability.}

The effect on viability of PGK,HGF and SCC4 cells treated with different concentrations of the fourchemical compounds chlorhexidine, aspartame, xylitol andsodium bicarbonate, over $24 \mathrm{~h}$ was assessed by using MTT method. All the compounds caused a decrease in cell viability of the tumor cells in a concentration and timedependent manner as compared to controls, however to varying degrees. A slightly higher cell viability, as compared to untreated cells, was observed for healthy all cells- PGK d)
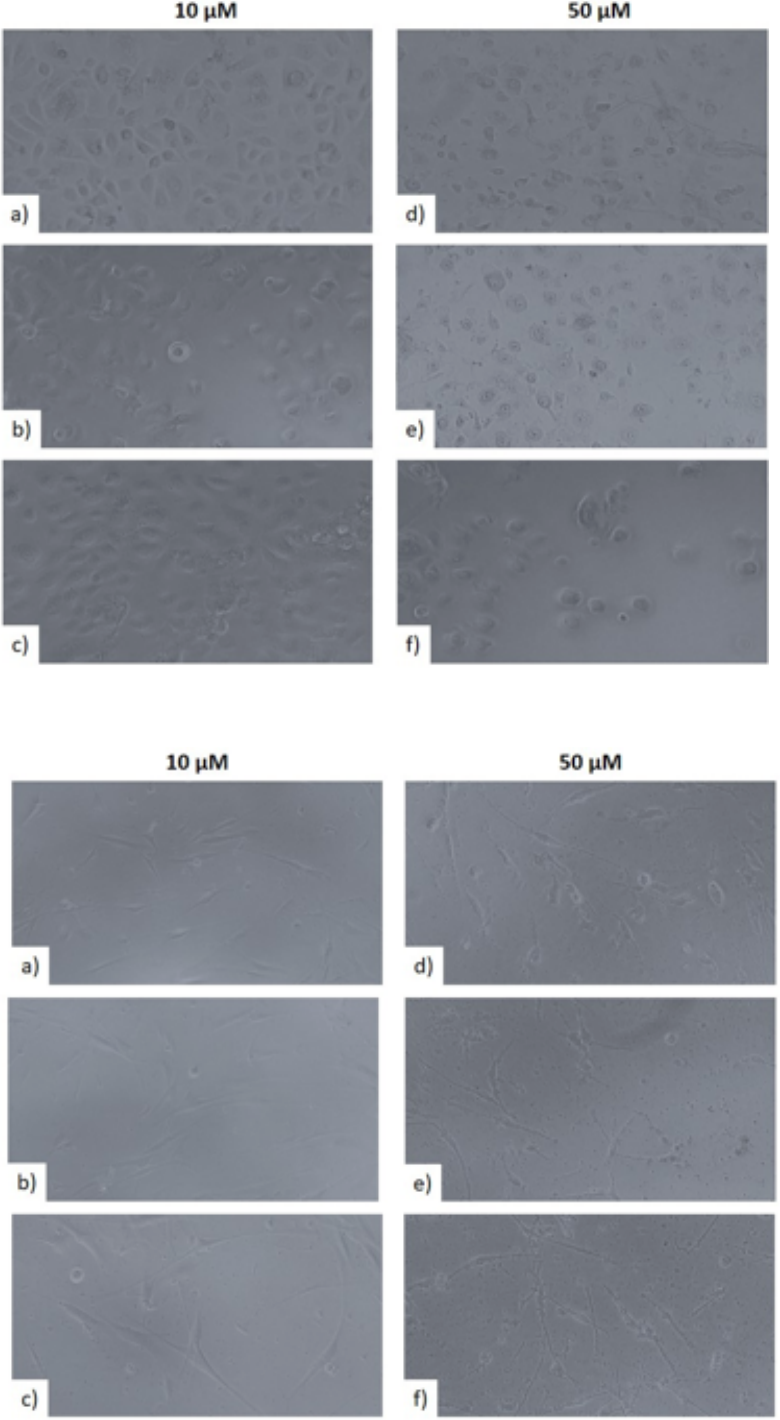

d)
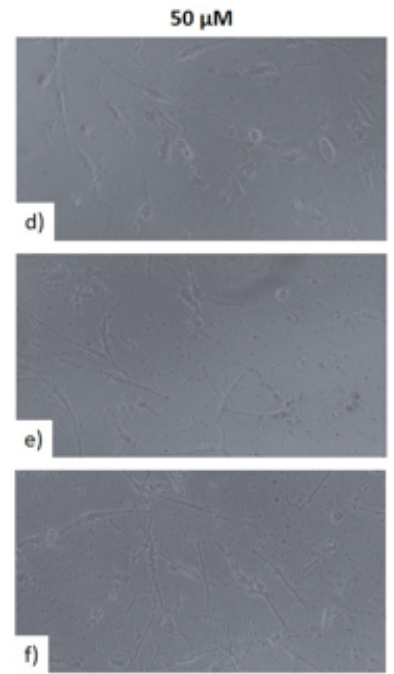

Fig. 1. Morphology of gingival keratinocytes cells at $24 \mathrm{~h}$ poststimulation with test compounds: a) and d) chlorhexidine;b) and e) aspartame; c) and f) xylitol
Fig. 2. Morphology of gingival fibroblasts cells at $24 \mathrm{~h}$ post-stimulation with test compounds: a) and d) chlorhexidine;b) and e) aspartame; c) and f) xylitol 

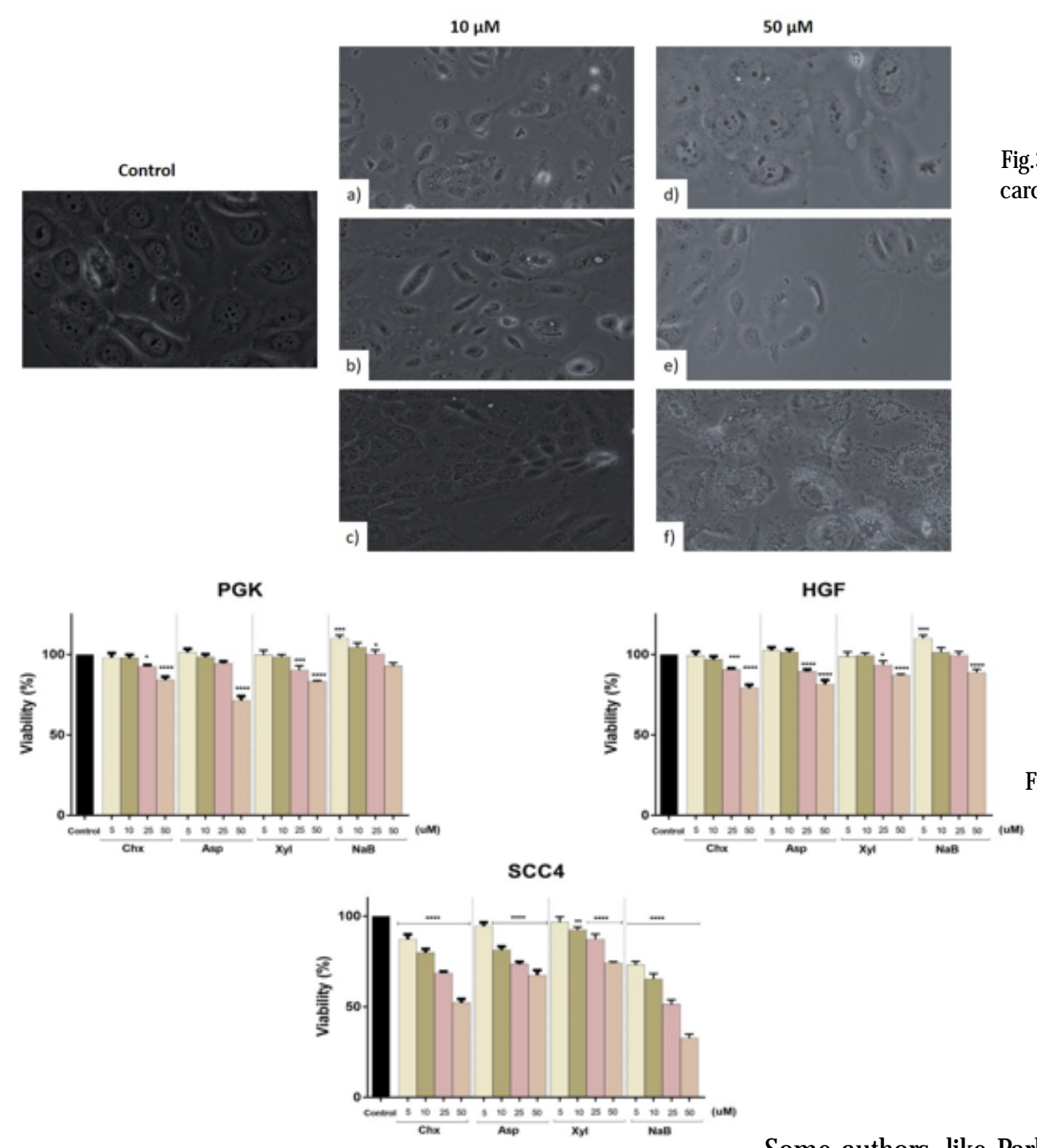

Fig. 4. Viability percentage of primary gingival keratinocytes (PGK) and fibroblasts (HGF) and squamous carcinoma (SCC4) at $24 \mathrm{~h}$ poststimulation with test compounds $(5,10,25$ and $50 \mu \mathrm{M})$
Fig.3. Morphology of tongue squamous carcinoma cells at $24 \mathrm{~h}$ post-stimulation with test compounds:

a) and d) chlorhexidine;b) and

e) aspartame; c) and f) sodium bicarbonate and HGF-when treated with low concentrations ofsodium bicarbonate (1-10 $\mu \mathrm{M})$, however exposure to chemical compoundsapplied in higher concentrations caused decreased cell viability in a dosedependentmanner. In case of PGK after post-stimulation with the compounds at 50 $\mu \mathrm{M}$ the viability was as follows: 84\% for Chx, $71 \%$ for Asp, 83\% for Xyl and 92\% for NaB while regarding HGF the percentage were: 79\% for Chx, 81\% for Asp, $87 \%$ for $\mathrm{Xyl}$ and $~ 88 \%$ for $\mathrm{NaB}$

After $24 \mathrm{~h}$ of incubation, no statistically significant differences could be detected between the following compounds, chlorhexidine, aspartame and xylitolat 5 and $10 \mu \mathrm{M}$ concentrations. The tests compounds concentrations starting at $10 \mu \mathrm{M}$ caused a decrease in cell viability in a dose-dependent manner for the SCC4 cells, and as can be seen in the figure 4, this cell line seemed to be more sensitive to all the compounds except xylitol compared to the healthy cell lines. For the SCC4 cell line the greatest decrease in cell viability was observed with chlorhexidine $(\sim 68 \%$ at $25 \mu \mathrm{M}$ and $\sim 52 \%$ at $50 \mu \mathrm{M})$ and sodium bicarbonate $(\sim 51 \%$ at $25 \mu \mathrm{M}$ and $\sim 33 \%$ at $50 \mu \mathrm{M})$.

Aspartame at low doses can be considered a potential angiogenic compound that can produce regenerative cytokine production. It enhances the specific markers and receptors and finally can be formed new blood vessels, which develop proper conditions that in vivo may result in the promotion of specific pathologies such as: diabetic retinopathies, rheumatoid arthritis and tumor cell invasion and spreading of metastases [12].

Some authors, like Park and collaborators stated that xylitol inhibited the proliferation of cancer cells such as A549, Caki, NCl-H23, HCT-15, HL-60, K562, and SK MEL-2 cells, but had less effect on the cell viability of HGF cells and also induces cell morphological changes and autophagy in lung cancer cells [13].

All these preliminary studies may have clinical relevance only after correlating with other in vivo detailed studies due to the fact that the utilized cells do not have the salivary pellicle layer, andcannot reproduce the immunologic issues in vivo or the protective barriers at the tissue level [14].

\section{Conclusions}

Chemical compounds, like disinfectants and artificial sweeteners are currently classified as safe for consumption in various products by many international regulatory bodies, while some of them are still classified to be used 'with caution' in some countries. The results obtained in this study offer important data regarding the influence of Chx, Asp, Xyl and $\mathrm{NaB}$ on cell lines behaviour but they must be extrapolated to the in vivo conditions. The present study serves to provide further information on the possible effect these agents have on mammalian cells, how ever further studies will have to be performed to clarify what exactly these effects might be.

AcknowledgmentThe present study was financially supported by an internal grant funded by Victor Babes University of Medicine and Pharmacy Timisoara [project no. P III-C4-PCFI-2016/2017-04]. 


\section{References}

1. MOHARAMZADEH, K. Biocompatibility of oral care products. Biocompatibility of Dental Biomaterials. 2017 Elsevier Ltd.

2. WATTS, A., ADDY, M. Br. Dent. J. 190, 2001, p. 309.

3. HELMS, J.A., DELLA-FERA, M.A., MOTT, A.E., FRANK, M.E. Arch. Oral Biol. 40, 1995, p. 913.

4. VARONI, E., TARCE, M., LODI, G., CARRASSI, A. Minerva. Stomatol. 61, 2012, p. 399.

5. SHANKAR, P., AHUJA, S., SRIRAM, K. Nutr. 29, 2013, p. 1293.

6. ABHILASH, M., PAUL, M.V.S., VARGHESE, M.V., NAIR, R.H. Food Chem. Toxicol. 49, 2011, p. 1203.

7. ASHOK, I., SHEELADEVI, R., WANKHAR, D. Biomed, 4, 2013, p. 39.
8. FAGHERAZZI, G., VILIER, A., SAES SARTORELLI, D. et al. Am. J. Clin. Nut 97, 2013, p. 517.

9. OKASHA, E.F. J. Micro. Ultrastruct., 4, 2016, p. 175.

10. CAROCHO, M., MORALES, P,. FERREIRA, I.C.F.R. Food ChemToxicol. 107, 2017,p. 302.

11. PINZARU, I., TRANDAFIRESCU, C., SZABADAI, Z., MIOC, M., LEDETI, I., CORICOVAC, D.et al. Rev Chim. (Bucharest), 65, no. 7, 2014, p. 848.

12. ALLEVA, R., BORGHI, B., SANTARELLI, L., STRAFELLA, E., CARBONARI, D., BRACCI, M. Toxicology in Vitro 25, 2011, p. 286.

13. PARK, E., PARK, M.H., NA, H.S., CHUNG, J. BiotechnolLett37, 2015, p. 983.

14. CVIKL, B., LUSSI, A., GRUBER, R. Eur J Oral Sci123, 2015, p. 179.

$\overline{\text { Manuscript received: } 17.03 .2018}$ 